\title{
The significant relationship between independent and student's motivation on online-based mathematics learning
}

Tetty Natalia Sipayung1*, Imelda ${ }^{1}$, Tatag Yuli Eko Siswono ${ }^{2}$, \& Masriyah $^{2}$

${ }^{1}$ Department of Mathematics Education, Universitas Katolik Santo Thomas, Medan, Indonesia, 20132

2 Department of Mathematics Education, Universitas Negeri Surabaya, Surabaya, Indonesia, 60213

*Corresponding author: tetty_sipayung@ust.ac.id | Phone Number: +082168325206

\section{ARTICLE INFO}

Received: 07-09-2021

Received in revised: 23-09-2021

Accepted: 18-10-2021

Available online: 30-10-2021

\section{KEYWORDS}

Relationship;

Motivation;

Independence;

Mathematics learning;

\begin{abstract}
A B S T R A C T
The purpose of this quantitative research with correlational design is to determine whether there is independent learning with learning motivation in online-based mathematics learning. So, it can support the success of learning process. This study was conducted in the odd semester of the 2021/2022 Academic Year. All seventh-grade students of SMP Santo Yoseph Medan were used as the research population. While the samples of this study were all students of class VII-A who collected 30 people and all students of class VII-B who collected 31 people. In mathematics learning, all students are taught online through the Zoom cloud meeting platform, WhatsApp, and Google Classroom. Sampling was done by purposive sampling technique. The study instruments is a learning independence questionnaire and student learning motivation questionnaire. The results of the questionnaire were analyzed based on product moment correlation data. Data analysis of the research results showed sig. (2-tailed) $<0.05$ so that there is a significant relationship between learning independence and students' learning motivation in online-based mathematics learning with a value of 0.433 including the category of moderate correlation.
\end{abstract}

\section{INTRODUCTION}

The view of the learning situation in schools, especially in mathematics classes, is an important thing. Fron an educational perspective, the importance of a situational view in strengthening cases, interactions, and collaborations in learning (Verschaffel, L., Greer, B., \& De Corte, E., 2010). In addition, mathematics is the foundation of basic science learning (Huang, C. S. J., Su, A. Y. S., Yang, S. J. H., \& Liou, H. H., 2017).

Until now mathematics is still included in the category of subjects that cause anxiety by most students. This of course has an impact on the low student learning outcomes. As a concrete example, the low mathematical ability of Indonesian students causes Indonesian students' mathematics achievement to be in the lowest rank in PISA. According to data published by the OECD, Indonesia is still consistently in the bottom 10. This is of course very worrying. The starting point of the finding with the conceptual model is that students' anxiety is caused by five factors, namely students and teachers in mathematics classes, curriculum, teaching strategies, classroom culture, and assessment (Žakelj, A., 2014). Specifically-mathematics success itself refers to students' perceptions of themselves as learners and their capacity to succeed in learning mathematics (Garcia, T., Rodríguez, C., Betts, L., Areces, D., \& González-Castro, P., 2016). Self-efficacy focuses on the description of individual abilities that reflect the individual's perception of his ability to take the necessary actions and in carrying out his duties to succeed (Hanin, V. \& Van Nieuwenhoven, C, 2016).

Therefore, we need a technique or learning method that is in accordance with the capacity of students in improving their mathematics learning outcomes. One of the learning techniques that is generally liked and helps students is learning accompanied by examples. Example-based learning is an effective and efficient learing carried out by novice students in acquiring new problem-solving skills (Van Harsel, M., Hoogerheide, V., Verkoeijen, P., \& van Gog, T., 2019). 
The success of learning does not rely only on the efforts of students, but also requires the efforts of the teacher. In informing pedagogical decisions to help students learn, many teachers have tried to understand student motivation (Walter, J. G., \& Hart, J., 2009). According to Sardiman, there are eight indicators of learning motivation, which include: (1) persevering in facing the task; (2) tenacious in facing difficulties; (3) showing interest in various problems; (4) prefer to work independently; (5) quickly bored on routine tasks; (6) can defend his opinion; (7) it is not easy to give up the things that are believed; (8) enjoy finding and solving problems (Nasrah, A. \& Muafiah, 2020). As a teacher, of course you are interested if students have persistence in solving problems and work together in solving problems carefully and designing solutions without procedural instructions (Walter, Janet \& Janelle Hart, 2009).

Mastery goal-oriented students tend to be more intrinsically motivated (Lapointe, J. M., Legault, F., \& Batiste, S. J., 2005). Motivation predicts learners' self-regulation strategies. In addition, motivation is an alternative component of self-regulation in predicting strategies (Berger, J. L. \& Karabenick, S. A., 2011). In the learning experience experienced by students, it will certainly create special memories for students. Memories are related to past failures and successes and have a motivational effect that can influence the way students complete difficult tasks (Finn, B., 2020). The development of student motivation is heterogeneous, which means that students differ in their self-concept and self-worth beliefs across subjects and beliefs in themselves that can change over time (Oppermann, E., Vinni-Laakso, J., Juuti, K., Loukomies, A., \& Salmela-Aro, K., 2020).

In addition to learning motivation, students' independence is also needed learning. In this digital era, students are expected to be independent in learning. The various online platforms developed are expected to be used as a means for learning. Students who are able to learn independently are students who are intellectually motivated by adopting effective and flexible learning strategies to cope with various learning and assessment tasks in them and do them well (Wong, I. H. M. \& Wong, T. T. Y., 2021). Students who are independent in learning are students who do not depend on others, are confident, have self-discipline, are responsible, have self-initiative, and have self-control. These six things are indicators of learning independence (Bernard, M. et. al., 2019).

In learning mathematics in this digital era, it is hoped that learning motivation and learning independence will begin to be embedded in students. Therefore, a quantitative study is needed to reveal whether there is a relationship between learning independence and student motivation in online-based mathematics learning. In relation to the learning motivation data in this study, the indicators used are not all indicators expressed by Sadirman, but only on some motivation indicators such as responsibility, trying to excel, liking challenges, being independent, having fortitude and persistence. It is hoped that using statistical test can answer the questions of whether there is a significant relationship between learning independence and student learning motivation.

\section{METHOD}

This study is a quantitative-research with a correlational design. The application of learning when research is carried out online through the Zoom cloud meeting platform, WhatsApp, and Google Classroom. This research was conducted in odd semesters in mathematics learning. The population of this study were all seventh-grade students of SMP Santo Yoseph Medan in the 2021/2022 academic year consisting of grades VII-A, VII-B, VII-C, and VII-D. The sample of this research was selected by purposive sampling technique so that the sample of this study was determined to be all students of class VII-A with a total of 30 students and all students of class VII-B with a total of 31 students. So, the total number of students in the research sample was 61 peoples.

In obtaining data from the results of the study, it was carried out using non-test instruments, namely a learning motivation questionnaire and a student learning independence questionnaire. The questionnaire was designed using the Linkert scale with five choices, namely strongly agree, agree, disagree, disagree, and strongly disagree. The designed questionnaire contains several items of positive statements and negative statements. The questionnaire is designed based on the indicators. The lattice of student learning motivation questionnaires are arranged in table 1 .

Table 1. Learning motivation questionnaire grid

\begin{tabular}{ccccc}
\hline \multirow{2}{*}{ No. } & \multirow{2}{*}{ Indicator } & \multicolumn{2}{c}{ Questionnaire Item Number } & Total \\
\cline { 3 - 5 } & & Positive & Negative & \\
\hline 1 & Responsibility & $2,8,18,29,30$ & $12,14,20$ & 8 \\
\hline 2 & Striving to exce & $5,6,19,28$ & 4,9 & 6 \\
\hline 3 & Like challenges & $21,23,25$ & $11,16,24$ & 6 \\
\hline 4 & Independence & $7,22,27$ & $3,15,26$ & 6 \\
\hline 5 & Fortitude & - & 1,17 & 2 \\
\hline 6 & Tenacity & 10,13 & - & 2 \\
\hline & Total & 17 & 13 & 30 \\
\hline
\end{tabular}

In the table 1 above, it is known that there are 30 statements in the learning motivation questionnaire. While the arrangement of the learning independence questionnaire grid can be seen in the following table 2 .

In the table 2 above, it is known that the number of statements in the student learning independence questionnaire also has 30 items. The data from the questionnaire before the correlation was analyzed, the data normality test was carried out first. 
Table 2. Learning independence questionnaire grid

\begin{tabular}{clccc}
\hline \multirow{2}{*}{ No. } & \multirow{2}{*}{ Indicator } & \multicolumn{2}{c}{ Questionnaire Item Number } & Total \\
\cline { 3 - 5 } & & Positive & Negative & \\
\hline 1 & Dependence on others & $1,2,3,4,5$ & - & 5 \\
\hline 2 & Have confidence & $7,8,10$ & 6,9 & 5 \\
\hline 3 & Behave discipline & $11,13,15,16,17$ & 12,14 & 7 \\
\hline 4 & $\begin{array}{l}\text { Have a sense of } \\
\text { responsibility }\end{array}$ & $18,21,22$ & 19,20 & 5 \\
\hline 5 & $\begin{array}{l}\text { Behave on your own } \\
\text { initiative }\end{array}$ & $23,24,25,26,27$ & - & 5 \\
\hline 6 & Doing self-control & 29,30 & 28 & 3 \\
\hline & Total & 23 & 7 & 30 \\
\hline
\end{tabular}

The formulation of normality test hypothesis is as follows:

$\mathrm{H}_{0}$ : Data are normally distributed or residual values are normally distributed.

$\mathrm{H}_{1}$ : Data is not normally distributed or the residual value is not normally distributed.

The basis for making the decision on the normality test of the data is based on the following criteria:

If asymp sig. (2-tailed) > 0,05 then $\mathrm{H}_{0}$ accepted and $\mathrm{H}_{1}$ rejected.

If asymp sig. (2-tailed) $\leq 0,05$ then $\mathrm{H}_{0}$ rejected and $\mathrm{H}_{1}$ accepted.

After testing the normality of the data, the results of the questionnaire were analyzed based on the product moment correlation data based on the Pearson Correlation value. The formulation of the correlation test hypothesis is as follows:

$\mathrm{H}_{0}$ : There is no significant relationship between learning independence and students' learning motivation in online-based mathematics learning.

$\mathrm{H}_{1}$ : There is a significant relationship between learning independence and students' learning motivation in online-based mathematics learning.

The basic for making the decision on the normality test of the data is based on following criteria:

If sig. $>0,05$ then $\mathrm{H}_{0}$ accepted and $\mathrm{H}_{1}$ rejected.

If sig. $\leq 0,05$ then $\mathrm{H}_{0}$ rejected and $\mathrm{H}_{1}$ accepted.

The Pearson Correlation value scale interval can be seen in the following table 3.

Table 3. Pearson Correlation value scale interval

\begin{tabular}{cc}
\hline Pearson Correlation Value Interval & Correlation Category \\
\hline $0,00-0,20$ & No correlation \\
\hline $0,21-0,40$ & Weak correlation \\
\hline $0,41-0,60$ & Medium correlation \\
\hline $0,61-0,80$ & Strong correlation \\
\hline $0,81-1,00$ & Perfect correlation
\end{tabular}

(Source: Rahmatih, A. K., et. al., 2020)

\section{RESULTS AND DISCUSSION}

\section{Data Analysis}

After the implementation of online-based mathematics learning was carried out in two classes with a total research sample of 61 people, the research sample was given a questionnaire of learning independence and student motivation to fill in according to actual conditions. The results of the questionnaire are in a statistical description in the following table 4.

Table 4. Descriptive statistics

\begin{tabular}{lcccccc}
\hline & $\mathrm{N}$ & Minimum & Maximum & Mean & Std. Dev. & Var. \\
\hline Independent & 61 & 93.00 & 146.00 & 117.6721 & 11.50612 & 132.391 \\
\hline Motivation & 61 & 93.00 & 133.00 & 109.7049 & 8.88134 & 78.878 \\
\hline $\begin{array}{l}\text { Valid N } \\
\text { (Listwise) }\end{array}$ & 61 & & & & & \\
\hline
\end{tabular}

Based on the table 4 above, it can be seen that results of the learning independence questionnaire filled out by 61 students had a minimum score of 93 , a maximum score of 146, an average score of 117,57 learning independence with a standard deviation of 11,51 and a variance of 132,39. While the results of the learning motivation questionnaire filled out by 61 students had a minimum score of 93, a maximum score of 133 , an average score of 109,7 for learning motivation with a standard deviation of 8,88 and a variance of 78,88 .

\section{Normality Test and Correlation Test}

Prior to the correlation test, the data normality test was first performed. The normality test of this study used the Kolmogorov-Smirnov Test. The purpose of this test is to determine whether the data used in the study is normally distributed or not. The test results can be seen in the table 5.

Table 5. One sample Kolmogorov-Smirnov test

\begin{tabular}{llr}
\hline & & Unstandardized Residual \\
\hline $\mathrm{N}$ & & 61 \\
\hline Normal Parameters ${ }^{\mathrm{a}, \mathrm{b}}$ & Mean & .0000000 \\
\cline { 2 - 3 } & Std. Deviation & 8.00474066 \\
\hline Most Extreme & Absolute & .053 \\
\cline { 2 - 3 } Differences & Positive & .032 \\
\cline { 2 - 3 } & Negative &. .053 \\
Test Statistic & & .053 \\
\hline Asymp. Sig. (2-tailed) & $.200^{\mathrm{c}, \mathrm{d}}$ \\
\hline a. Test distribution is Normal. & \\
b. Calculated from data. & \\
\multicolumn{2}{l}{$\begin{array}{l}\text { c. Lilliefors Significance Correction. } \\
\text { d. This is a lower bound of the true significance. }\end{array}$}
\end{tabular}

Based on the data in the table above, information is obtained that sig. $>0,05$, it means that the data on learning independence and learning motivation are normally distributed. Furthermore, to find out whether there is a significant relationship between learning independence 
and learning motivation, a correlation test is carried out. Correlation test data can be seen in the following table 6 .

Table 6. Correlations

\begin{tabular}{llrr}
\hline & & Independent & Motivation \\
\hline \multirow{2}{*}{ Independent } & Pearson Correlation & 1 & $.433^{* *}$ \\
\cline { 2 - 4 } & Sig. (2-tailed) & & .000 \\
\cline { 2 - 4 } & $\mathrm{N}$ & 61 & 61 \\
\hline Motivation & Pearson Correlation & $.433^{* *}$ & 1 \\
\cline { 2 - 4 } & Sig. (2-tailed) & .000 & 61 \\
\cline { 2 - 4 } & $\mathrm{N}$ & 61 & \\
\hline
\end{tabular}

**. Correlation is significant at the 0.01 level (2-tailed).

Based on the table 6 data above, sig (2-tailed) i. e. 0,000 $<0,05$ indicates that there is a significant relationship between learning independence and students' learning motivation in online-based mathematics learning. In addition, information obtained that the Pearson Correlation value is 0,433 , the correlation is positive and the value is in the medium category interval.

\section{CONCLUSION}

Based on the results of the research and discussion above, it is concluded that there is a significant relationship between learning independence and learning motivation in online-based mathematics learning situations that are applied with a Pearson Correlation value of 0,433. Based on the Pearson Correlation value scale interval, it is known that the relationship is in the medium category.

\section{Acknowledgements}

The authors would like to thank the research grants for the Inter-University Cooperation Research Scheme provided by the Ministry of Education and Culture Research and Technology based on the decree number 9/E1/KPT/2021 and the contract agreement number 165/LL1/PG/2021 between the Higher Education Service Institutions. Region 1 with the Institute for Research and Community Service of Universitas Katolik Santo Thomas so that this research is carried out well and the results can be published in this scientific article.

\section{REFERENCES}

Berger, J. L. \& Karabenick, S. A. (2011). Motivation and student' use of learning strategies: Evidence of unidirectional effects in mathematics classrooms. Learning and Instruction, 21(3), 416-428.

Bernard, M. et. al. (2019). Enhance learning independence and self-ability of exceptional children through developing learning media VBA for excel games. Journal of Physics: Conf. Series, 1315, 012037, 1-10.

Finn, B. (2020). Exploring interactions between motivation and cognition to better shape self-regulated learning. Journal of Applied Research in Memory and Cognition, 9(4), 461-467.

Garcia, T., Rodriguez, C., Betts, L., Areces, D., \& Gonzalez-Castro, P. (2016). How affective-motivational variables and approaches to learning predict mathematics achievement in upper elementary levels. Learning and Individual Differences, 49, 25-31.

Hanin, V. \& Van Nieuwenhoven, C. (2016). The influence of motivational and emotional factors in mathematical learning in secondary education. Revue Europeenne de Psychologie Appliquee/European Review of Applied Psychology, 66(3), 127-138.

Huang, C. S. J., Su., A. Y. S., Yang, S. J. H., \& Liou, H. H. (2017). A collaborative digital pen learning approach to improving students' learning achievement and motivation in mathematics courses. Computers \& Education, 107, 31-44.

Lapointe, J. M., Legault, F., \& Batiste, S. J. (2005). Teacher interpersonal behavior and adolescents' motivation in mathematics: A comparison of learning disabled, average, and talented students. International Journal of Educational Research, 43(1-2), 39-54.

Nasrah, A. \& Muafiah. (2020). Analisis Motivasi Belajar dan Hasil Belajar Daring Mahasiswa Pada Masa Pandemik Covid-19. Jurnal Riset Pendidikan Dasar, 03(2), 207-213.

Oppermann, E., Vinni-Laakso, J., Juuti, K., Loukomies, A., \& Salmela-Aro, K. (2020). Elementary school students' motivational profiles across finish language, mathematics and science: Longitudinal trajectories, gender differences and STEM aspirations. Contemporary Educational Psychology, 101927.

Rahmatih, A. K., et. al. (2020). Hubungan motivasi dan kemandirian belajar mahasiswa calon guru Sekolah Dasar. Wahana Sekolah Dasar, 28(2), 76-83.

Walter, J. G. \& Hart, J. (2009). Understanding the complexities of student motivations in mathematics learning. The Journal of Mathematical Behavior, 28(2-3), 162-170.

Wong, I. H. M. \& Wong, T. T. Y. (2021). Exploring the relationship between intellectual humility and academic performance among post-secondary students: The mediating roles of learning motivation and receptivity of feedback. Learning and Individual Differences, 88, 102012.

Van Harsel, M., Hoogerheide, V., Verkoeijen, P. \& Van Goog, T. (2019). Effects of different sequences of examples and problems on motivation and learning. Contemporary Educational Psychology, 58, 260-275.

Verschaffel, L., Greer, B., \& De Corte, E. (2010). Matematics Learning. International Encyclopedia of Education, 401406.

Zakelj, A. (2014). Support to pupils with learning difficulties in mathematics. Procedia-Social and Behavioral Sciences, 159, 506-511. 